\title{
Improvement in Bone Density with Calcitriol Substitution for Cholecalciferol in Refractory Osteoporosis induced by Prednisone
}

\author{
Udaya M Kabadi* and Salina Esmail \\ Division of Endocrinology, Broadlawns Medical Center, Adjunct Professor of Medicine, University of Iowa Iowa City, Iowa \\ *Correspondence to: Udaya M Kabadi MD, FACP, FACE, FRCP(C), Division of Endocrinology, Broadlawns Medical Center, Adjunct Professor of Medicine, University \\ of Iowa, Iowa City, Iowa; Tele No. 5152823041; Email: ukabadi@gmail.com;
}

Received: August 06, 2018; Accepted: August 17, 2018; Published: August 27, 2018;

\section{Summary}

Low BMD in subjects receiving chronic prednisone therapy is attributed to osteoporosis. This study demonstrates that osteomalacia induced by lowering of biologically active vitamin D by prednisone induced inhibition of hepatic 25 hydroxyase may also be a major contributing factor.

\begin{abstract}
Introduction/ Purpose: Decline in BMD following prednisone therapy is attributed to osteoporosis. However, osteomalacia due to low $125 \mathrm{OH}$ Vitamin $\mathrm{D}$ and resulting hyperparathyroidism may also be contributors. Therefore, administration of $125 \mathrm{OH}$ vitamin D3, Calcitriol on BMD was examined in subjects receiving chronic prednisone therapy and low $\mathrm{BMD}(\mathrm{T}<2.5)$ refractory to therapy with bisphosphanate, calcium and vitamin $\mathrm{D} 3$, Cholecalciferol.

Methods: 21 subjects, ages 45-56 years receiving prednisone $\geq 3$ years with declining BMD despite therapy with Cholecalciferol, CaCO3 and bisphosphanate were divided into 2 groups. Both groups continued Calcium and bisphosphanate. 10 subjects (group 1) received increased dose of Cholecalciferol, 2000 units daily while in 11 subjects (group 2), it was substituted by Calcitriol. Comprehensive metabolic panels (CMP) including serum calcium and alkaline phosphatase as well as $25 \mathrm{OH}$ Vit D and $125 \mathrm{OH}$ Vit D levels were determined every 6 months. BMD was determined at yearly interval.
\end{abstract}

Results: CMP including calcium and phosphorus remained normal in both groups while alkaline phosphatase declined in group 2 alone. Serum 25 $\mathrm{OH}$ Vit D levels were subnormal $(<20 \mathrm{pg} / \mathrm{ml})$ in both groups and normalized $(53 \pm 6 \mathrm{pg} / \mathrm{ml})$ only in group 2 . BMD continued to decline in group1 while improving $(\mathrm{p}<0.01)$ in group 2; BMD being significantly greater than group $1(\mathrm{p}<0.01)$.

Conclusion: In subjects receiving chronic prednisone therapy, low BMD is induced by multiple mechanisms: osteomalacia caused by decreased $125 \mathrm{OH}$ Vit D and osteoporosis caused by matrix collagen breakdown, hypogonadism and secondary hyperparathyroidism. Role of osteomalacia is confirmed by rising BMD on substituting active $125 \mathrm{OH}$ vitamin D3, Calcitriol for inactive vitamin D3, Cholecalciferol.

Key Words: Prednisone, Osteoporosis, Osteomalacia, Low 125 OH Vitamin D, Hyperparathyroidism

\section{Introduction}

Occurrence of a significant decline in bone mineral density (BMD) following chronic therapy with immunosuppressive agents including prednisone in subjects undergoing organ transplant is well established [1-4]. Many organizations have recommended repeatedly over last several years, use of therapeutic agents in conjunction with life style modification including appropriate weight bearing exercises as tolerated by individual subject as well as adequate daily intake of vitamin D, mostly cholecalciferol 1200 units and elemental calcium, $1200-1500 \mathrm{mg}$ in order to prevent or improve decline in bone mineral density [5-10]. Unfortunately though, the progress in implementation of these guidelines regarding preventive and therapeutic strategies has been apparently slow and less than adequate for unclear reasons [11-20].
The decline in BMD is mainly attributed to osteoporosis secondary to bone resorption [21-25]. However, several other factors may contribute to pathogenesis. Central hypogonadism caused by suppression of hypothalamic pituitary gonadal axis by prednisone may be a contributing factor $[26,27]$. Alternatively, osteomalacia caused by low circulating biologically active $125 \mathrm{OH}$ vitamin D induced via inhibition of hepatic hydroxylase by Prednisone may be another major pathophysiologic contributor [28-30]. Therefore, we examined impact of administration of biologically active $125 \mathrm{OH}$ vitamin D3 (Calcitriol) on BMD in subjects receiving prednisone and lack of significant $(3 \%)$ improvement in low BMD $(\mathrm{T}<2.5)$ despite persistent therapy with biologically inert vitamin D3 Cholecalciferol, calcium and Risedronate (Proctor and Gamble Pharmaceuticals, USA) continuously over prior 3 years. 


\section{Subjects and Methods}

21 adult subjects, 17 women and 4 men with ages $45-56$ years while receiving prednisone $\geq 10 \mathrm{mg}$ daily continuously for $\geq 3$ years were referred to Endocrinology clinic at an academic Medical Center for further assessment and management for lack of improvement in low bone mineral density assessed at 2 consecutive years despite being concurrently administered daily vitamin D3 (Cholecalciferol) 1200 units, Calcium carbonate (elemental calcium, 1200- $1500 \mathrm{mg}$ ) and Risedronate $5 \mathrm{mg}$. All subjects had received organ transplants, e.g. Liver, kidney or heart prior to administration of prednisone along with other immunosuppressive agents, cyclosporine and methylphenidate. All women had ceased to have menstrual cycles at the time of enrollment. Subjects being treated for chronic disorders e.g. hypertension, dyslipidemia, diabetes mellitus, coronary artery disease, hypothyroidism etc were included if stable while receiving medications in the same daily dose for duration of at least 6 months prior to entry into the study. Exclusion criteria included hospitalization for surgery, myocardial infarction, stroke and uncontrolled diabetes mellitus during 6 months prior to entry into the study. Subjects manifesting elevated liver enzymes $>2 \mathrm{x}$ normal, decreased effective glomerular filtration rate $<50 \mathrm{ml} /$ hour and disorders of calcium metabolism and inability to sign informed consent were excluded as well.

The subjects were divided into 2 groups. In 10 subjects, 8 women and 2 men (group 1), vitamin D3 Cholecalciferol was increased to 2000 units daily while in group 2 consisting of 11 subjects, 9 women and 2 men, Cholecalciferol was substituted by $125 \mathrm{OH}$ vitamin D3 Calcitriol (Rocaltrol, Validus Pharmaceuticals, Parsippany, New Jersey, USA) $0.5 \mathrm{mcg}$ daily. All subjects in both groups continued Calcium and Risedronate ( Actonel, Warner Chilcott (US), LLC Rockaway, NJ 07866, USA) in the same daily doses. Subjects also continued to receive immunosuppressive drugs and other previously prescribed medications for management of other disorders in the same daily dose. Hormone replacement therapy in post menopausal women and testosterone administration in men were continued with the same formulations and the same daily dose as well. Comprehensive metabolic panels (CMP) including serum calcium, phosphorus and alkaline phosphatase as well as $25 \mathrm{OH}$ Vit D and $125 \mathrm{OH}$ Vit D levels were determined by local laboratory in all subjects prior to grouping and at every 6 months until the end of the period of observation. BMD was determined by DEXA using the same equipment (Hologic) at yearly interval. The subjects were followed every 3 months to ensure adherence and compliance with therapeutic recommendations as well as for adverse events.

\section{Results}

In all participants, comprehensive metabolic panels including serum urea nitrogen, creatinine, liver enzymes, electrolytes, calcium and phosphorus concentrations were all normal prior to the entry into study and remained without significant changes at 2 years. However, serum alkaline phosphatase levels were normal prior to entry and remained unaltered in all subjects in group 1 whereas they were elevated in 8 out of 11 subjects in group 2 but declined significantly in all subjects individually as well as a group. Serum $25 \mathrm{OH}$ Vit D (< $20 \mathrm{ng} / \mathrm{ml}$ ) were subnormal at entry into the study prior to increasing the daily dose of Cholecalciferol in group 1 and prior to change over to Calcitriol in group 2 and remained unaltered in both groups at the end of observation period of 2 years. In contrast, $125 \mathrm{OH}$ Vit D levels were subnormal $(<25 \mathrm{pg} / \mathrm{ml})$ in both groups prior to entry into study and remained subnormal in group 1 (Table1). Moreover, in subjects belonging to group 2, $125 \mathrm{OH}$ Vit $\mathrm{D}$ concentrations normalized by 6 months and remained within normal range at 2 years (Table 1). BMD (T score) continued to decline in group1 (Table 2) whereas in group 2, BMD improved significantly from baseline within a year and the improvement was progressive till the end of the study period at 2 years (Table2). Thus, BMD in group 2 was significantly greater at both year 1 and year 2 in comparison to group $1(\mathrm{p}<0.01)$.

Table 1: 25 Hydroxy (OH) Vitamin D and $125 \mathrm{OH}$ vitamin D in subjects increasing Cholecalciferol daily dose (Group1) and changing to Calcitriol (Group 2)

\begin{tabular}{|c|c|c|c|c|c|}
\hline Time in years & $\mathbf{- 2}$ & $\mathbf{- 1}$ & $\mathbf{0}$ & $\mathbf{1}$ & $\mathbf{2}$ \\
\hline 25 OH Vit D Group 1 & $20 \pm 3$ & $19 \pm 4$ & $22 \pm 5$ & $20 \pm 4$ & $24 \pm 5$ \\
\hline 25 OH Vit D Group 2 & $21 \pm 3$ & $22 \pm 5$ & $21 \pm 4$ & $22 \pm 5$ & $23 \pm 5$ \\
\hline 125 OH Vit D Group 1 & $18 \pm 2$ & $19 \pm 3$ & $18 \pm 3$ & $21 \pm 4$ & $21 \pm 5$ \\
\hline 125 OH Vit D Group 2 & $18 \pm 3$ & $19 \pm 4$ & $19 \pm 5$ & $48 \pm 7^{* \dagger}$ & $53 \pm 6^{* \dagger}$ \\
\hline
\end{tabular}

$* \mathrm{p}<0.01$ vs Group 1

$\uparrow \mathrm{p}<0.001$ VS 0 TIME IN Group 2

Table 2: Bone Mineral density (BMD) in subjects increasing Cholecalciferol daily dose (Group1) and changing to Calcitriol (Group 2)

\begin{tabular}{|c|c|c|c|c|c|}
\hline Time in Years & $\mathbf{- 2}$ & $\mathbf{- 1}$ & $\mathbf{0}$ & $\mathbf{1}$ & $\mathbf{2}$ \\
\hline BMD Group 1 & $-2.8 \pm 0.2$ & $-3.0 \pm 0.3$ & $-2.9 \pm 0.3$ & $-3.1 \pm 0.3$ & $-3.3 \pm 0.1$ \\
\hline BMD Group 2 & $-2.9 \pm 0.3$ & $-3.0 \pm 0.4$ & $-3.1 \pm 0.3$ & $-2.6 \pm 0.2 * \dagger$ & $-2.3 \pm 0.1 * \dagger$ \\
\hline
\end{tabular}

$* \mathrm{p}<0.05$ vs Time 0

$\uparrow \mathrm{p}<0.01$ vs Group 1

\section{Discussion}

The decline in BMD in subjects receiving immunosuppressive therapy including prednisone may be attributed to multiple factors [2130]. Enhanced catabolism of matrix collagen induced by prednisone apparently plays a major pathophysiologic role in osteoporosis as evident by increased bone resorption [21-26]. Alternatively, central hypogonadism caused by suppression of hypothalamic pituitarygonadal axis by prednisone is also a contributing factor [27-30]. Moreover, osteomalacia due to decline in circulating biologically active $125 \mathrm{OH}$ Vitamin D secondary to lowered $25 \mathrm{OH}$ Vitamin D due to inhibition of hepatic 25 hydroxylase induced by prednisone may facilitate the decline in BMD [31-35]. Finally, secondary hyperparathyroidism in response to decreased active vitamin $\mathrm{D}$ may also promote the decline in BMD [21-26,31-35].

This study demonstrates that BMD continued to decline in subjects in group 1 despite increasing the daily dose of vitamin D3, Cholecalciferol while continuing other therapeutic strategy including drugs. This data is consistent with several previous clinical trials using same therapeutic strategies including either drugs inhibiting bone resorption or anabolic agents and vitamin D3, Cholecalciferol or its 
derivative, alfacalcifedol [31,32,34-39]. In contrast, supplementation with calcitriol following substitution for Cholecalciferol improved bone mineral density markedly in our study (Table 2). Lack of improvement or even stability of BMD may be attributed to impaired generation of $25 \mathrm{OH}$ vitamin $\mathrm{D}$ from Cholecalciferol due to inhibition of hepatic 25 hydroxylase by prednisone resulting in persistent lowering of biologically active $125 \mathrm{OH}$ vitamin $\mathrm{D}$ concentration (Table1). Alternatively, a marked rise in biologically active $125 \mathrm{OH}$ vitamin D levels on administration of Calcitriol instead of cholecalciferol (Table1) may have contributed to improvement in BMD via promotion of bone mineralization and inhibition of bone resorption induced by normalization of PTH. Thus, the decline or lack of stabilization or improvement in BMD in subjects receiving prednisone is a consequence of osteomalacia and secondary hyperparathyroidism in conjunction with bone resorption caused by matrix protein catabolism and hypogonadism as described previously. In the final analysis, it is apparent that decline in BMD induced by prednisone is multi factorial and is induced by osteomalacia due to lack of adequate biologically active $125 \mathrm{OH}$ Vitamin D and concurrently increased bone resorption secondary to matrix collagen breakdown induced by prednisone itself as well as exacerbation by secondary hyperparathyroidism and hypogonadism. Moreover, appropriate therapy consisting of Calcitriol and adequate calcium supplementation as well as sex hormones and antiresorptive or anabolic agents based on pathophysiology alone is likely to maintain preservation or promote improvement in BMD in subjects receiving chronic prednisone administration. Therefore, we recommend that guidelines for management of glucocorticoid induced bone disease include calcitriol for vitamin D supplementation as an integral part of a total protocol including all therapeutic modalities.

Acknowledgements: The data was presented in part at Endocrine Society's 96th Annual Meeting and Expo, June, 2014

Conflict of Interest: The author Udaya M Kabadi declares that he has no conflict of interest and no disclosures.

\section{References}

1. Rich GM, Mudge GH, Laffel GL, LeBoff MS. Cyclosporine A and prednisoneassociated osteoporosis in heart transplant recipients. J Heart Lung Transplant. 1992 Sep-Oct; 11(5): 950-8.

2. Tałałaj M, Gradowska L, Marcinowska-Suchowierska E, Durlik M, Gaciong Z, Lao M. Efficiency of preventive treatment of glucocorticoid-induced osteoporosis with 25-hydroxyvitamin D3 and calcium in kidney transplant patients. Transplant Proc. 1996 Dec; 28(6): 3485-7.

3. Cremer J, Strüber M, Wagenbreth I, Nischelsky J, Demertzis S, Graeter T, Abraham C, Haverich A. Progression of steroid-associated osteoporosis after heart transplantation. Ann Thorac Surg. 1999 Jan; 67(1): 130-3.

4. Monegal A, Navasa M, Guañabens N, Peris P, Pons F, Martínez de Osaba MJ, Rimola A, Rodés J, Muñoz-Gómez J Bone mass and mineral metabolism in liver transplant patients treated with FK506 or cyclosporine A. Calcif Tissue Int. 2001 Feb; 68(2): 83-6.

5. Torregrosa JV, Moreno A, Gutierrez A, Vidal S, Oppenheimer F. Alendronate for treatment of renal transplant patients with osteoporosis. Transplant Proc. 2003 Jun; 35(4): 1393-5.

6. Adler RA1, Hochberg MC. Suggested guidelines for evaluation and treatment of glucocorticoid-induced osteoporosis for the Department of Veterans Affairs. Arch Intern Med. 2003 Nov 24; 163(21): 2619-24.

7. Pereira RM, Carvalho JF, Paula AP, Zerbini C, Domiciano DS, Gonçalves H, Danowski JS, Marques Neto JF, Mendonça LM, Bezerra MC, Terreri MT, Imamura M, Weingrill P, Plapler PG, Radominski S, Tourinho T, Szejnfeld VL, Andrada $\mathrm{NC}$; Committee for Osteoporosis and Bone Metabolic Disorders of the Brazilian Society of Rheumatology; Brazilian Medical Association; Brazilian Association of Physical Medicine and Rehabilitation. Guidelines for the prevention and treatment of glucocorticoid-induced osteoporosis.Rev Bras Reumatol. 2012 Aug; 52(4): 580 93. English, Portuguese.

8. Thanou A, Ali T, Haq O, Kaitha S, Morton J, Stavrakis S, Humphrey MB Utilization of Preventive Measures for Glucocorticoid-Induced Osteoporosis among Veterans with Inflammatory Bowel Disease. ISRN Gastroenterol. $2013 \mathrm{Apr}$ 21; 2013: 862312. doi: 10.1155/2013/862312. Print 2013. Erratum in: Int Sch Res Notices. 2017 Sep 18; 2017: 2365840.

9. Mazzantini M1, Di Munno O Glucocorticoid-induced osteoporosis: 2013 update. Reumatismo. 2014 Jul 28; 66(2): 144-52. doi: 10.4081/reumatismo.2014.787.

10. Briot S K, Cortet B, Roux C, Fardet L, Abitbol V, Bacchetta J, Buchon D, Debiais F, Guggenbuhl P, Laroche M, Legrand E, Lespessailles E, Marcelli C, Weryha G, Thomas T; Bone Section of the French Society for Rheumatology (SFR) and Osteoporosis Research and Information Group (GRIO). 2014 update of recommendations on the prevention and treatment of glucocorticoid-induced osteoporosis. Joint Bone Spine. 2014 Dec; 81(6): 493-5

11. Buckley L, Guyatt G, Fink HA, Cannon M, Grossman J, Hansen KE, Humphrey MB, Lane NE, Magrey M, Miller M, Morrison L, Rao M, Robinson AB, Saha S, Wolver S, Bannuru RR, Vaysbrot E, Osani M, Turgunbaev M, Miller AS, McAlindon T. 2017 American College of Rheumatology Guideline for the Prevention and Treatment of Glucocorticoid-Induced Osteoporosis.Arthritis Rheumatol. 2017 Aug; 69(8): 1521-1537. doi: 10.1002/art.40137. Epub 2017 Jun 6. Review. Erratum in: Arthritis Rheumatol. 2017 Nov; 69(11): 2246.

12. Yood RA, Harrold LR, Fish L, Cernieux J, Emani S, Conboy E, Gurwitz J. Prevention of glucocorticoid-induced osteoporosis: experience in a managed care setting. Arch Intern Med. 2001 May 28; 161(10): 1322-7.

13. Curtis JR, Westfall AO, Allison JJ, Becker A, Casebeer L, Freeman A, Spettell CM, Weissman NW, Wilke S, Saag KG. Longitudinal patterns in the prevention of osteoporosis in glucocorticoid-treated patients.Arthritis Rheum. 2005 Aug; 52(8): 2485-94.

14. van Staa TP. The pathogenesis, epidemiology and management of glucocorticoidinduced osteoporosis. Calcif Tissue Int. 2006 Sep; 79(3): 129-37. Epub 2006 Sep 11.

15. Cruse LM, Valeriano J, Vasey FB, Carter JD. Prevalence of evaluation and treatment of glucocorticoid-induced osteoporosis in men. J Clin Rheumatol. 2006 Oct; 12(5): 221-5.

16. Civitelli R, Ziambaras K. Epidemiology of glucocorticoid-induced osteoporosis. J Endocrinol Invest. 2008 Jul; 31(7 Suppl): 2-6.

17. Weinstein RS. Clinical practice. Glucocorticoid-induced bone disease. N Engl J Med. 2011 Jul 7; 365(1): 62-70. doi: 10.1056/NEJMcp1012926.

18. McKeown E, Bykerk VP, De Leon F, Bonner A, Thorne C, Hitchon CA, Boire G, Haraoui B, Ferland DS, Keystone EC, Pope JE; CATCH Investigators. Quality assurance study of the use of preventative therapies in glucocorticoid-induced osteoporosis in early inflammatory arthritis: results from the CATCH cohort. Rheumatology (Oxford). 2012 Sep; 51(9): 1662-9. Epub 2012 Apr 25.

19. Massafra U, Migliaccio S, Bancheri C, Chiacchiararelli F, Fantini F, Leoni F, Martin LS, Migliore A, Muccifora B, Napolitano C, Pastore R, Ragno A, Ronzoni S,Rotondi M, Tibaldi M, Villa P, Vinicola V, D'Erasmo E, Falaschi P, Minisola $G$ Approach in glucocorticoid-induced osteoporosis prevention: results from the Italian multicenter observational EGEO study. J Endocrinol Invest. 2013 Feb; 36(2): 92-6. doi: 10.3275/8288. Epub 2012 Mar 6.

20. Thanou A, Ali T, Haq O, Kaitha S, Morton J, Stavrakis S, Humphrey MB. Utilization of Preventive Measures for Glucocorticoid-Induced Osteoporosis among Veterans with Inflammatory Bowel Disease. ISRN Gastroenterol. $2013 \mathrm{Apr}$ 21; 2013: 862312. doi: 10.1155/2013/862312. Print 2013.

21. Naranjo A, López R, García-Magallón B, Cáceres L, Francisco F, Jiménez-Palop M, Ojeda-Bruno S. Longitudinal practice patterns of prophylaxis of glucocorticoidinduced osteoporosis in patients with polymyalgia rheumatica. Rheumatol Int. 2014 Oct; 34(10): 1459-63. doi: 10.1007/s00296-014-3014-2. Epub 2014

22. Conti A, Sartorio A, Ferrero S, Ferrario S, Ambrosi B. Modifications of biochemical markers of bone and collagen turnover during corticosteroid therapy. J Endocrinol Invest. 1996 Feb; 19(2): 127-30.

23. Ardissone P, Rota E, Durelli L, Limone P, Isaia GC. Effects of high doses of corticosteroids on bone metabolism. J Endocrinol Invest. 2002 Feb; 25(2): 129-33

24. Ton FN, Gunawardene SC, Lee H, Neer RM. Effects of low-dose prednisone on bone metabolism. J Bone Miner Res. 2005 Mar; 20(3): 464-70. Epub 2004 Nov 29.

25. Mitra R. Adverse effects of corticosteroids on bone metabolism: a review. PM R. 2011 May; 3(5): 466-71; quiz 471. doi: 10.1016/j.pmrj.2011.02.017. Review.

26. Kauh E, Mixson L, Malice MP, Mesens S, Ramael S, Burke J, Reynders T, Van Dyck K, Beals C, Rosenberg E, Ruddy M. Prednisone affects inflammation, glucose tolerance, and bone turnover within hours of treatment in healthy individuals. Eur J Endocrinol. 2012 Mar; 166(3): 459-67. doi: 10.1530/EJE-11-0751. Epub 2011 Dec 17.

27. Martens HF, Sheets PK, Tenover JS, Dugowson CE, Bremner WJ, Starkebaum G. Decreased testosterone levels in men with rheumatoid arthritis: effect of low dose prednisone therapy. J Rheumatol. 1994 Aug; 21(8): 1427-3 
28. Odell W. Testosterone treatment of men treated with glucocorticoids. Arch Intern Med. 1996 Jun 10; 156(11): 1133-4.

29. Kung AW, Chan TM, Lau CS, Wong RW, Yeung SS.Osteopenia in young hypogonadal women with systemic lupus erythematosus receiving chronic steroid therapy: a randomized controlled trial comparing calcitriol and hormonal replacement therapy. Rheumatology (Oxford). 1999 Dec; 38(12): 1239-44.

30. Crawford BA, Liu PY, Kean MT, Bleasel JF, Handelsman DJ. Randomized placebocontrolled trial of androgen effects on muscle and bone in men requiring long-term systemic glucocorticoid treatment. J Clin Endocrinol Metab. 2003 Jul; 88(7): $3167-76$.

31. Kano K, Suda T. Serum $25(\mathrm{OH}) \mathrm{D}$ and $24,25(\mathrm{OH}) 2$ levels in childhood nephrosis under different therapeutic regimens of steroid administration. Eur J Pediatr. 1982 Mar; 138(2): 162-5

32. Rickers H, Deding A, Christiansen C, Rødbro P, Naestoft J. Corticosteroid-induced osteopenia and vitamin D metabolism. Effect of vitamin D2, calcium phosphate and sodium fluoride administration. Clin Endocrinol (Oxf). 1982 Apr; 16(4): 409-15.

33. Lems WF, Van Veen GJ, Gerrits MI, Jacobs JW, Houben HH, Van Rijn HJ, Bijlsma JW. Effect of low-dose prednisone (with calcium and calcitriol supplementation) on calcium and bone metabolism in healthy volunteers. Br J Rheumatol. 1998 Jan; 37(1): 27-33.

34. Guzman-Clark JR, Fang MA, Sehl ME, Traylor L, Hahn TJ. Barriers in the management of glucocorticoid-induced osteoporosis. Arthritis Rheum. 2007 Feb $15 ; 57(1): 140-6$.

35. Mok CC, Ying KY, To CH, Ho LY, Yu KL, Lee HK, Ma KM. Raloxifene for prevention of glucocorticoid-induced bone loss: a 12-month randomised doubleblinded placebo-controlled trial. Ann Rheum Dis. 2011 May; 70(5): 778-84. doi; 10.1136/ard.2010.143453. Epub 2010 Dec

36. Lakatos P, Nagy Z, Kiss L, Horvath C, Takacs I, Foldes J, Speer G, Bossanyi Prevention of corticosteroid-induced osteoporosis by alfacalcidol. Z Rheumatol. 2000; 59 Suppl 1: 48-52.
37. de Nijs RN, Jacobs JW, Lems WF, Laan RF, Algra A, Huisman AM, Buskens E, de Laet CE, Oostveen AC, Geusens PP, Bruyn GA, Dijkmans BA, Bijlsma JW; STOP Investigators. Alendronate or alfacalcidol in glucocorticoid-induced osteoporosis. N Engl J Med. 2006 Aug 17; 355(7): 675-84.

38. de Nijs RN, Jacobs JW, Lems WF, Laan RF, Algra A, Huisman AM, Buskens E, de Laet CE, Oostveen JC, Geusens PP, Bruyn GA, Dijkmans BA, Bijlsmat JW. [Alendronate more effective than alfacalcidol in the prevention of osteoporosis in patients with rheumatic disease who are starting glucocorticoid therapy]. Ned Tijdschr Geneeskd. 2007 May 26; 151(21): 1178-85. Dutch.

39. Hoes JN, Jacobs JW, Hulsmans HM, De Nijs RN, Lems WF, Bruyn GA, Geusens PP, Bijlsma JW.High incidence rate of vertebral fractures during chronic prednisone treatment in spite of bisphosphonate or alfacalcidol use. Extension of the alendronate or alfacalcidol in glucocorticoid-induced osteoporosis-trial. Clin Exp Rheumatol. 2010 May-Jun; 28(3): 354-9. Epub 2010 Jun 23.

40. Dechant KL, Goa KLCalcitriol. Areview of its use in the treatment of postmenopausal osteoporosis and its potential in corticosteroid-induced osteoporosis. Drugs Aging. 1994 Oct; 5(4): 300-17

41. Lambrinoudak, Chan DT, Lau CS, Wong RW, Yeung SS, Kung AW Effect of calcitriol on bone mineral density in premenopausal Chinese women taking chronic steroid therapy. A randomized, double blind, placebo controlled study. J Rheumatol. $2000 \mathrm{Jul} ; 27(7):$ 1759-65.

42. Neuhaus R, Kubo A, Lohmann R, Rayes N, Hierholzer J, Neuhaus P Calcitriol in prevention and therapy of osteoporosis after liver transplantation. Transplant Proc. 1999 Feb-Mar; 31(1-2): 472-3.

43. Sivri A, Karaduman A, Gökçe-Kutsal Y, Atakan N. Calcitriol treatment of glucocorticoid-induced osteoporosis in subjects with pemphigus vulgaris. J Eur Acad Dermatol Venereol. 2002 Jan; 16(1): 89-91.

44. Chen Y, Wan JX, Jiang DW, Fu BB, Cui J, Li GF, Chen CM.Efficacy of calcitriol in treating glucocorticoidinduced osteoporosis in patients with nephrotic syndrome: an open-label, randomized controlled study. Clin Nephrol. 2015 Nov; 84(5): 262-9. doi: $10.5414 / \mathrm{CN} 108473$

\section{Citation:}

Udaya M Kabadi and Salina Esmail (2018) Improvement in Bone Density with Calcitriol Substitution for Cholecalciferol in Refractory Osteoporosis induced by Prednisone. Endocrinol Diabetes Metab J Volume 2(3): 1-4 